\title{
The distributional impact of recurrent immovable property taxation in Greece
}

\author{
EIRINI ANDRIOPOULOU, Ph.D.* \\ ELENI KANAVITSA, Ph.D. candidate* \\ CHRYSA LEVENTI, Ph.D.* \\ PANOS TSAKLOGLOU, Prof.*
}

\section{Article**}

JEL: D31, H22

https://doi.org/10.3326/pse.44.4.4

\footnotetext{
* An earlier version of the paper was presented at the Public Sector Economics 2019 Conference on "Wealth and property taxation: where do we stand?" (Zagreb), where useful comments were provided by conference participants and, especially, the discussant of the paper, Ivica Urban. Very useful comments and suggestions were received from two anonymous referees. The research of Eleni Kanavitsa was co-financed by Greece and the EU (ESF) through the Operational Program "Human Resources Development, Education and Lifelong Learning" (project "Strengthening Human Resources Research Potential via Doctorate Research", MIS-5000432), while the research of Eirini Andriopoulou and Panos Tsakloglou was supported through Research Grant No EP-3035-01 of Athens University of Economics and Business. The views expressed in the article are those of the authors and should not be attributed to the Council of Economic Advisors.

${ }^{* *}$ Received: January 30, 2020
}

Accepted: August 31, 2020

\section{Eirini ANDRIOPOULOU}

Council of Economic Advisors, Hellenic Ministry of Finance and Athens University of Economics and Business, Nikis 5-7, 10563 Athens, Greece

e-mail: e.andriopoulou@minfin.gr

ORCiD: 0000-0003-4788-4563

\section{Eleni KANAVITSA}

Athens University of Economics and Business, 76 Patission Str., 10434 Athens, Greece

e-mail: ekanavitsa@aueb.gr

ORCiD: 0000-0002-2417-7439

\section{Chrysa LEVENTI}

Council of Economic Advisors, Hellenic Ministry of Finance, University of Essex and Athens University of Economics and Business, Nikis 5-7, 10563 Athens, Greece e-mail: c.leventi@minfin.gr

ORCiD: 0000-0002-1756-9207

\section{Panos TSAKLOGLOU}

Athens University of Economics and Business, IZA and Hellenic Observatory (LSE), 76 Patission Str., 104 34 Athens, Greece

e-mail: tsaklog@aueb.gr

ORCiD: 0000-0003-4625-3794 


\section{Abstract}

During the last decade, Greece faced one of the most severe debt crises among developed countries, leading to Economic Adjustment Programs in order to avoid a disorderly default. Public expenditure was cut, tax rates were increased and new taxes were introduced, aiming at restoring public finances. Prominent among the latter were recurrent property taxes that had played a very minor role before the crisis. These taxes helped to boost public revenues but were hugely unpopular. The paper examines in detail their distributional impact and finds that they led to increases in inequality and (relative) poverty. The result is stronger in the case of inequality indices that are relatively more sensitive to changes close to the bottom of the distribution and poverty indices that are sensitive to the distribution of income among the poor.

Keywords: property taxation, inequality, poverty, progressivity, Greece

\section{INTRODUCTION}

During the 1995-2007 period Greece's average growth rate was 3.9\% per annum; second only to Ireland among the Eurozone countries and 1.5\% above the Eurozone mean. However, Greece's growth model was based primarily on the expansion of consumption and was largely financed by the inflow of external funds. Even though Greek banks were not directly exposed to American subprime bonds, when the economic recession following the Lehman Brothers collapse erupted, the deficiencies of this model became apparent. In 2008 output stagnated and in 2009 the economy moved into full recession. Internal and external imbalances that had been growing steadily in earlier years deteriorated and the economy faced enormous "twin deficits" (in the general government budget and the current account); the deficit in the current account exceeded 15\% of GDP in 2008 and the budget deficit was over 15\% in 2009. In 2010 Greece was cut off from the international capital markets and in order to avoid a disorderly default had to rely on the help of her Eurozone partners and the IMF, through three Economic Adjustment Programs that lasted for eight years (2010-2018). ${ }^{1}$

In the framework of these programs, Greece agreed to rebalance its public finances through both expenditure cuts and tax increases. As shown in Graph 1, before the Economic Adjustment Programs Greece's share of taxes in GDP fluctuated around $33 \%$, far below the EU average (close to 39\%). In the years of the Economic Adjustment Programs Greece's share of taxes in GDP rose rapidly and stabilized above the EU average, close to $41 \%$. During this period, almost all tax rates were increased, while new taxes were introduced. As a result, the share of all types of taxes in GDP (direct taxes, indirect taxes, social insurance contributions and property taxes) rose, as shown in Graph 2. Regarding property taxes, although their share in GDP is small, it rose markedly after the introduction of a new property tax in 2011.

\footnotetext{
${ }^{1}$ Ioannides and Pissarides (2015), Tsakloglou et al. (2016) and Meghir et al. (2017) provide accounts of the Greek crisis.
} 


\section{Graph 1}

Tax revenues share of GDP, Greece and EU28, 2006-2016

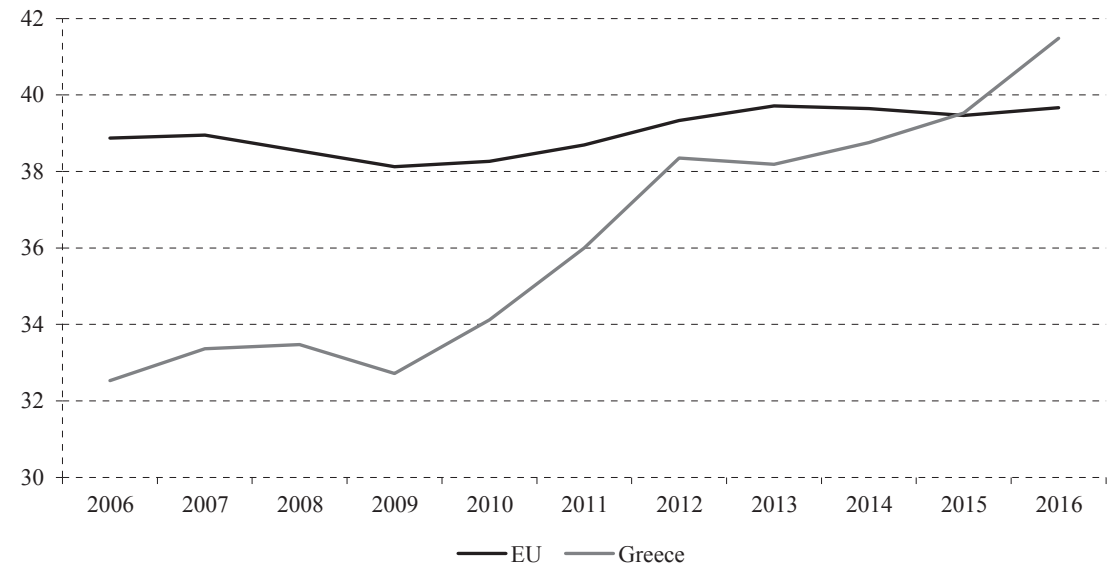

Source: AMECO (2020).

\section{GraPh 2}

Taxes as shares of GDP, Greece, 2006-2016

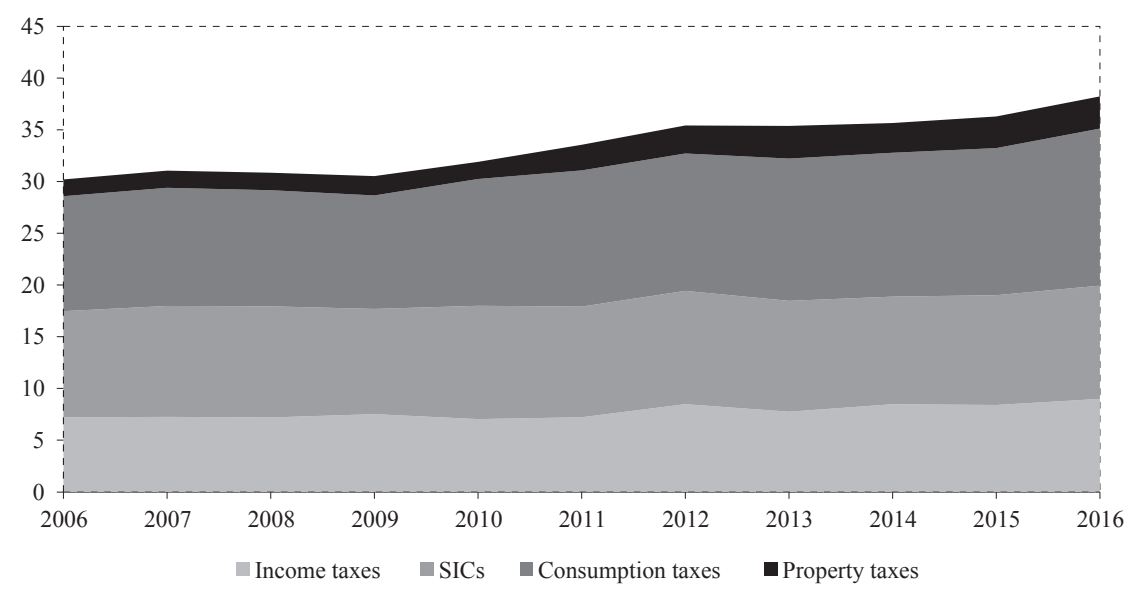

Source: Eurostat (2018).

As Mirrlees et al. (2011:368) point out "Most taxes nowadays are levied on flows of income and of expenditure. But land and property have been taxed for centuries - certainly for longer than income - and they continue to form an important part of the tax base in most advanced economies". Property taxation and especially, the taxation of land, has been popular among economists mainly on efficiency grounds. Following Ramsey (1927), Diamond and Mirrlees (1971) show that this type of taxation causes far fewer distortions than other types of taxes, particularly since it affects labour supply decisions minimally and hence, ceteris paribus, can be considered a tool to maximize production and welfare. Moreover, due to the 
immovable nature of real estate, property taxation is usually associated with high rates of collectability, making it popular among policy makers (Cabral and Hoxby, 2012)..$^{2}$

However, in most cases property taxes are hugely unpopular among the members of the general population (Norregaard, 2013). Mirrlees et al. (2011) conjecture that this unpopularity may be due to the fact that in most countries income and consumption taxes are withheld at source and remitted to the government by firms for the majority of the population. Therefore, property taxes may be the only or the largest taxes that are paid directly by taxpayers and are not withheld at any stage. Further, there is evidence that a considerable proportion of the population think that it is unfair to tax housing property (Lyons, 2007) particularly since, at least in the short run, these taxes are independent of someone's current income and, hence, ability to pay (Slack and Bird, 2014). This unpopularity may be mitigated in cases where property taxes are local taxes and are somehow considered "service charges" to the local community, thus collectively increasing local property values (Musgrave and Musgrave, 1989).

The expected distributional incidence of property taxes depends on the tax base (primary residence only, all housing, industrial buildings, agricultural land, other land types, etc.), the tax rates applied both within and across types of real estate as well as the tax relief measures applied. In general, it was expected that since property is a form of capital and capital is more concentrated than income, the redistributive effects of property taxation should be progressive (Aaron, 1974). However, empirical studies in several countries show that usually property taxes constitute a higher fraction of the income of lower rather than higher income deciles $^{3}$, thus increasing rather than reducing inequality; see, for example, the results of Kim and Lambert (2009), Davis et al. (2009) and Joumard, Pisu and Bloch (2012) for the United States, Chawla and Wannell (2003) and Palameta and Macredie (2005) for Canada and Joumard, Pisu and Bloch (2012) for the United Kingdom. On the opposite side, Marical (2009) reports that, due to a number of generous income- and family-related tax reliefs, recurrent taxes on immovable property in France are marginally progressive. In the case of Greece, although the contribution of these taxes to the stabilization effort of the economy was significant, their distributional effects have not yet been investigated. The present research aims to fill this gap.

The remainder of the paper is organized as follows. Section 2 provides a description of property taxation in Greece in a comparative perspective vis-à-vis other EU countries. Section 3 presents the data and methods used in the empirical analysis. Section 4 contains the empirical results on the distributional effects of recurrent immovable property taxation in Greece. Section 5 provides the conclusions.

\footnotetext{
${ }^{2}$ Moreover, property taxes can also be used as policy tools in order to manage urban density, land use and housing market prices as well as speculation and "bubbles" in real estate and, thus, economic cycles.

${ }^{3}$ Throughout the text, the term "decile" denotes "decile group" rather than "decile point".
} 
Traditionally, immovable property taxation in Greece relied on non-recurrent taxes (taxes on transactions, inheritances and in-vivo transfers of immovable property). Usually, such taxes accounted for around $0.4 \%-0.5 \%$ of GDP. Before the 2000 s, several attempts to introduce recurrent property taxation were unsuccessful mainly due to lack of property valuations. In the 2000 s, with a proper valuation system in place covering most parts of the country, a number of attempts to introduce such taxes under various schemes took place, the most important of which were: the Unified Real Estate Duty (ETAK), the Tax on Large Real Estates (FMAP) and the Municipal Real Estate Duty (TAP). Nevertheless, as shown in Graph 3, the revenues raised from these schemes remained very low (between $0.1 \%$ and $0.2 \%$ of GDP).

\section{GrAPH 3}

Immovable property taxes in Greece as shares of GDP, 2007-2016

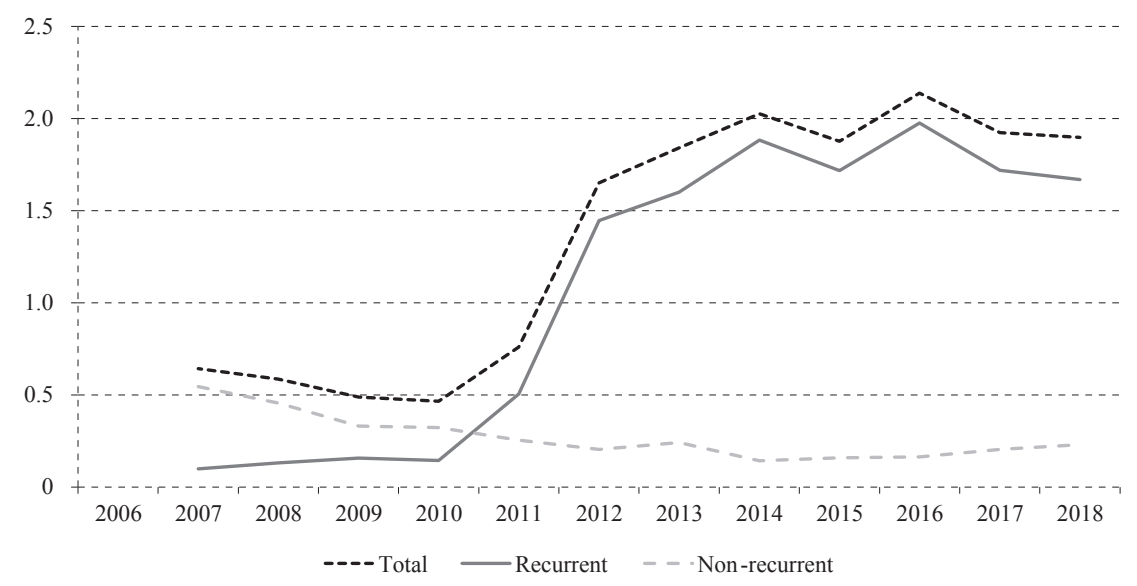

Source: Hellenic Ministry of Finance, General Accounting Office and AMECO (2020).

The picture changed dramatically during the crisis, due to the urgent need to increase revenues. In 2011, the Emergency Special Duty of Buildings Connected to the Electricity Grid (EETHDE) was introduced. The tax was applied only to buildings, both private households and firms being eligible for payments and, in order to achieve a high collection rate, it was collected through electricity bills. ${ }^{4}$ In 2014, the Unified Real Estate Property Tax (ENFIA) replaced EETHDE and was extended to the possession of land. On top of this, a supplementary tax was introduced for individuals with a total taxable property value of over 200,000 euros (covering the top $8 \%$ of the distribution of natural persons); it was aimed at introducing some progressivity into the scheme. Moreover, reduced rates applied to some of the most vulnerable population groups. Since 2014, changes in the

\footnotetext{
${ }^{4}$ The tax was introduced in late 2011 and the tax bill could be paid in installments. Most units eligible to the tax paid part of it in 2011 and part in 2012. For this reason, in Graph 3 only part of the effect of the introduction of the tax is recorded in 2011.
} 
level of tax have taken place mainly in order to introduce further tax deductions for vulnerable groups and gradual deleverage with successive horizontal tax rate deductions in the most recent years.

As shown in Graph 3, after the introduction of EETHDE and, especially, ENFIA, the share of recurrent immovable property taxes in national income shot up, reaching $2.0 \%$ of GDP. Collection rates were high. For example, according to the General Accounting Office data for 2018, the collection rate of ENFIA was 84\%. ${ }^{5}$ At the same time, due to the crisis, real estate transactions declined sharply leading to a fall in non-recurrent property tax revenues as a share of GDP and recurrent taxes accounted for the lion's share of property taxes.

The recurrent taxes introduced in the period under consideration were assessed at the individual level and the tax base for the calculation of the tax was the taxable value of each asset. This, in turn, was determined mainly by the (administratively assessed) value of the geographical zone of the real estate asset. A major problem with the assessment of these taxes was that during the crisis property market values declined by over $40 \%$ (Bank of Greece, 2019: Table II.6), while their taxable values remained unchanged. The problem was further complicated because Greece lacks a complete cadastral registry and the re-assessment of detailed taxable values would have been a very hard exercise given the low number of transactions in the real estate market during the crisis. This is a usual drawback of real estate taxes in practice in many countries. As Almy (2014) points out, valuation practices frequently ignore revaluation requirements, which almost by definition occur in periods of rapid recession or growth. This lack of revaluation can enhance the perception of taxpayers that property taxes may be unfair. It should be noted that these taxes were introduced close to the peak of the Greek crisis. Output was down by $26 \%$, the rate of unemployment was above $27 \%$, while the disposable income of the average household was $42 \%$ below its peak (Andriopoulou et al., 2018). Unsurprisingly, the new tax was hugely unpopular and, according to many commentators, contributed to the downfall of the then government in the 2015 elections.

\footnotetext{
${ }^{5}$ The corresponding rate for the non-withheld part of personal income taxes was $77 \%$ and even lower for
} indirect taxes. 


\section{GraPH 4}

Total and recurrent property taxes as shares of GDP, Greece and EU28, 2006-2016

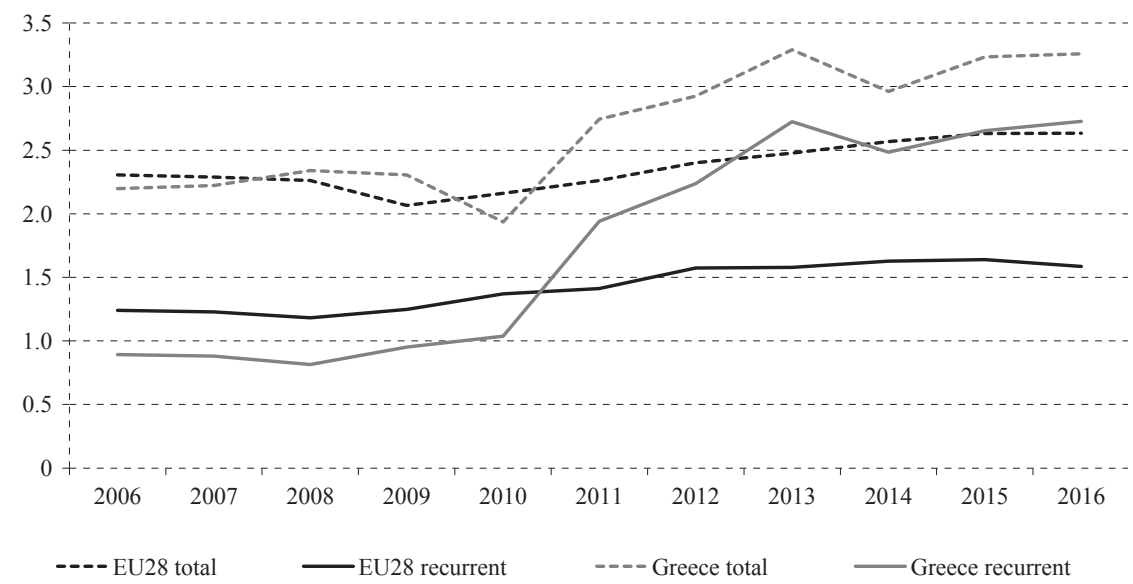

Source: Eurostat (2020).

Graphs 4 and 5 compare Greece with other EU countries with respect to revenues collected through property taxation. ${ }^{6}$ Graph 4 shows that until 2010 Greece was lagging behind the European average in terms of the share of property taxes in GDP. The gap can be attributed exclusively to the difference in the share of taxes collected through recurrent taxes. After 2010, though, the picture changes completely. Due to the introduction of EETHDE and, then, ENFIA, the share of both recurrent and total property taxes in Greece's GDP exceed the European average by a wide margin; in the last year under consideration in Graph 4, the differences are $1.1 \%$ and $0.6 \%$ of GDP, respectively.

\footnotetext{
${ }^{6}$ These graphs refer to property taxation in general; not only immovable property taxation. However, in all countries the latter is the main component of property taxation.
} 


\section{GraPh 5}

Property taxes as shares of GDP in EU28, 2017

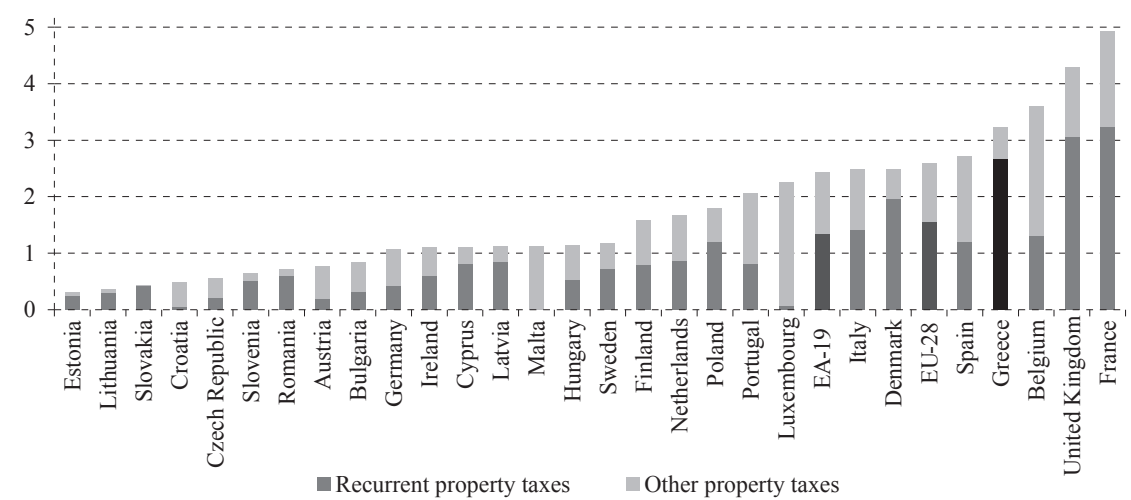

Source: European Commission, Taxation Trends (2019).

Graph 5 shows that in 2017 Greece's share of property taxes in GDP was the fourth highest in the EU (behind France, the UK and Belgium), while in terms of the share of recurrent property taxes in GDP, only two countries were collecting higher revenues than Greece (France and the United Kingdom). Furthermore, Greece's share of property taxes in total taxes collected ( $8 \%$ ) is substantially higher than the corresponding mean EU figure (6\%) (European Commission, 2019).

\section{GraPH 6}

Intertemporal changes in Poverty Rate (AROP, lhs) and Gini index (rhs), Greece and EU28, 2006-2016

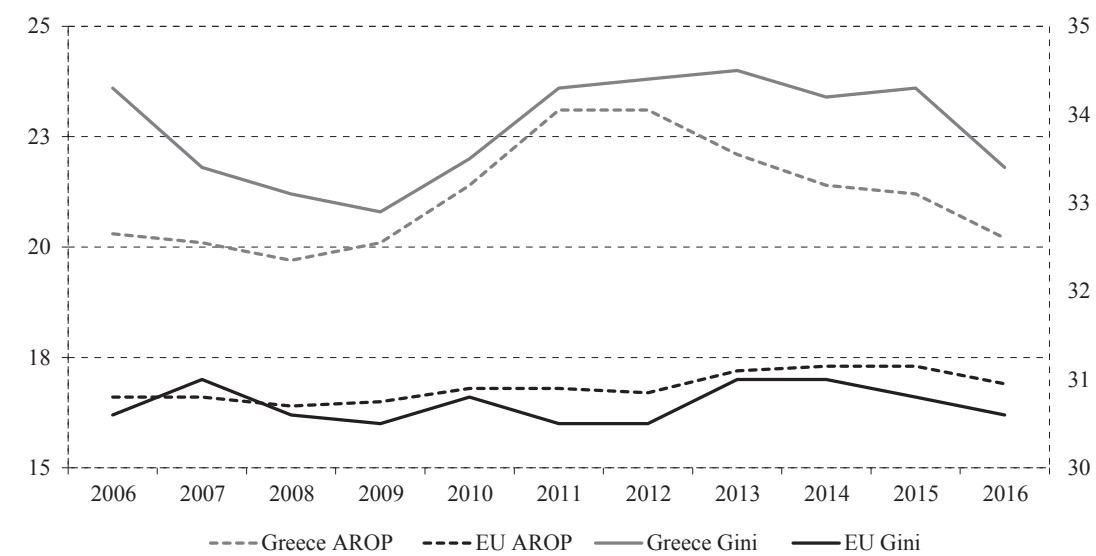

Source: Eurostat (2020).

Finally, before moving to the empirical results, a few words on changes in inequality and poverty in Greece during the period under consideration are needed. Despite the dramatic changes in living standards of the Greek population during this period, the evidence of Graph 6 that reports intertemporal changes in the Gini 
index and the poverty rate when the poverty line is set at $60 \%$ of the median equivalized income of the contemporaneous distribution suggest that the changes in inequality and poverty were not that large. Both of the indices remained substantially higher than the EU averages in Greece during this period, rose in the early years of the Economic Adjustment Programs following the sharp increase in unemployment rate and declined in later years. Nevertheless, detailed analysis using inequality indices that are more sensitive than the Gini index to changes close to the tails of the income distribution (especially the bottom end of the distribution) and poverty indices that are sensitive to the depth of poverty as well as the distribution of income among the poor in Andriopoulou, Karakitsios and Tsakloglou (2018) and Andriopoulou, Kanavitsa and Tsakloglou (2020) records stronger changes in inequality - although the pattern is similar to that of Graph 6 - and very considerable rises in poverty using "floating" and, especially, "anchored" poverty lines. Interestingly, unlike what is often heard in the Greek public discourse, the elderly improved their relative position while there was substantial deterioration in the relative position of the enlarged group of the unemployed, who swelled the ranks of the poor.

\section{DATA AND METHODS}

The data used in the paper are drawn from the Statistics on Income and Living Conditions (SILC) for Greece. We use SILC waves 2007 to 2017, corresponding to income years 2006 to 2016 . The data set contains information on property taxes paid. The information appears to be very reliable. For example, in 2017 the sum of recurrent property taxes reported in SILC was 2.3 billion euro, while the total reported by the tax authorities was 2.7 billion euro. However, the latter figure also includes recurrent property taxes paid by firms as well as households.

Due to the complexity of income surveys, such income data only become available with a considerable delay. For instance, the EU-SILC 2020 survey data (reporting incomes earned in 2019) will not be released before 2022. Tax-benefit microsimulation models can fill this gap, providing timely estimates of the effects of changes in taxes and benefits on the income distribution (Figari, Paulus and Sutherland, 2015). In order to assess the distributional impact of changes in property taxation in the most recent years (i.e. 2017, 2018 and 2019) we make use of the Greek component of EUROMOD, the tax-benefit microsimulation model of the EU.

EUROMOD is a tool that enables researchers to estimate in a comparable way the effects of taxes and benefits on the income distribution. The model simulates personal tax and social insurance contribution liabilities as well as cash benefit entitlements for all EU countries based on the national tax-benefit policy rules of a given year and the information available in the underlying microdata. The components of the tax-benefit systems that cannot be simulated are taken directly from the data, along with information on original incomes. EUROMOD has been validated at both micro and macro level and has been extensively used to address a broad range of economic and social policy questions (Sutherland and Figari, 
2013). One of the most important advantages of EUROMOD is attribution; the model allows researchers to isolate the effects of each policy, taking into account the complex ways in which policies interact with each other.

In this paper, EUROMOD's underlying microdata are drawn from SILC 2017. Updating incomes and non-simulated benefits from 2017 to 2019 is carried out using factors based on available administrative or survey statistics. Specific updating factors are derived for each income source, reflecting statutory rules or the change in the average amount per recipient between the income data reference period and the target year. In order to enhance the credibility of our estimates, an effort has been made to address issues such as tax evasion and benefit non-takeup. ${ }^{7}$ It should be noted that the estimates of inequality, poverty and progressivity indices reported below with the use of EUROMOD are not strictly comparable with the estimates derived from SILC data. The differences in the simulated results and the results derived from SILC can be attributed primarily to the simulation of several benefits in EUROMOD that are severely under-reported in SILC data (Tammik, 2019). When these corrections are made in EUROMOD, the incomes of a number of poor households rise and the corresponding estimates of inequality and poverty indices are lower than those derived from SILC. Therefore, these estimates are shown primarily in order to identify trends in recent years for which SILC data are not available.

For the period 2017-2019, the applicable property tax is ENFIA. As noted earlier, it consists of two parts: the primary and the supplementary. The primary tax is computed with an elaborate formula that, amongst other parameters, takes account of the cadastral value of the property, its surface, use and age as well as the floor on which it is located. There is also a social provision that grants discounts of $50 \%$ or $100 \%$ on the tax assessed to taxpayers with low family income, families of 3 or more dependent children, or with members suffering serious disabilities. The supplementary tax is applicable for taxpayers with properties whose cadastral values exceed $€ 200,000$. The value of ENFIA is reported in SILC. However, since SILC provides no information on properties' cadastral values, the policy is switched off in the baseline and the tax for 2017-2018 is taken directly from the input data (only minor changes were implemented in these years). However, in 2019 ENFIA was reduced by $10 \%-30 \%$ depending on the cadastral value of the property. ${ }^{8}$ This reduction is simulated in EUROMOD. In order to approximate properties' values, we used the average cadastral values for urban and rural/semi-rural areas according to tax data provided by the Greek authorities (i.e. $€ 1,338$ per square meter for those residing in urban areas and $€ 745$ per square meter for those residing in rural/ semi-rural areas).

\footnotetext{
${ }^{7}$ Detailed information about each of these issues as well as validations against external sources are available in the EUROMOD Country Reports for Greece.

${ }^{8}$ By $30 \%$ when the total cadastral value of the properties was below 60,000 euros, by $27 \%$ if it was between 60,000 and 70,000 , by $25 \%$ if it was between 70,000 and $80,000,20 \%$ if it was between 80,000 and $1,000,000$ and $10 \%$ if it was above $1,000,000$ euros.
} 
For the calculation of inequality, poverty and progressivity indices as well as for the classification of the members of the population in particular decile groups we used the member's equivalized household disposable income. This is the sum of all incomes of all household members net of income taxes and social insurance contributions (and, when needed, property taxes) divided by the household equivalence scale. The latter is used by EUROSTAT, which assigns 1 to the household head, 0.3 to each household member aged below 14 and 0.5 to each of the remaining household members.

\section{EMPIRICAL RESULTS}

\section{GRAPH 7}

Recurrent property taxes per capita per year, in euro, (lhs) and as share of disposable income, in \%, (rhs)

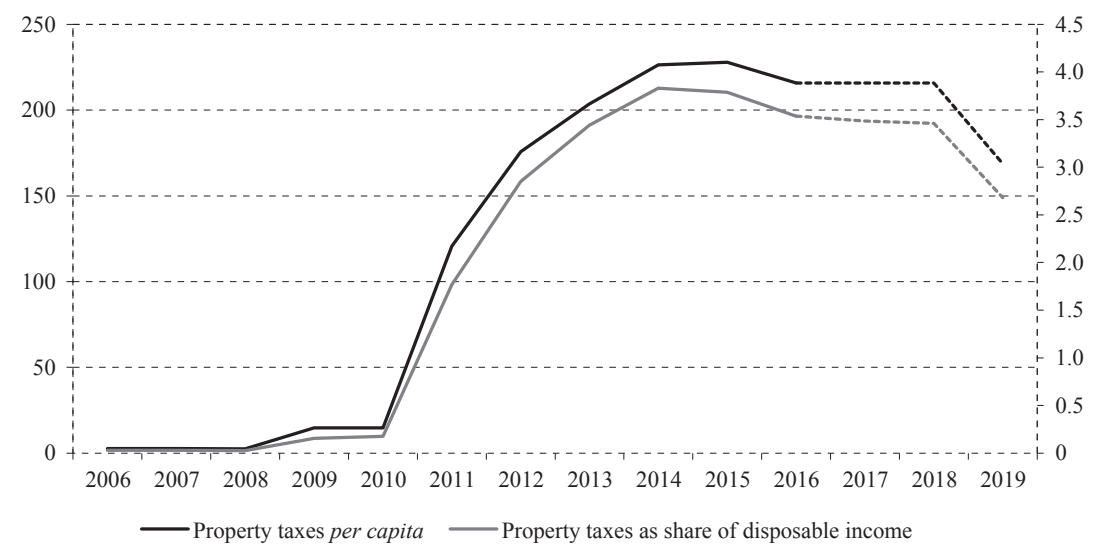

Source: ELSTAT, SILC (2007-2017) and EUROMOD.

Recurrent immovable property taxes per capita over time are shown in Graph 7 along with their share in household disposable income. For the first years of the period under examination, the recurrent property taxes in per capita terms are close to zero, while the introduction of ETAK in 2009 led to marginal increases. However, the introduction of EETHDE in 2011 increased sharply the amount of tax individuals paid from $€ 15$ on average in 2010 to $€ 175$ in 2012 . Two years later, when EETHDE was replaced by ENFIA, the corresponding figure rose further, reaching a maximum of $€ 225$ in 2015 . Since then, property taxes per capita started to decline due to reductions of cadastral values in many areas across the country and the introduction of tax exceptions for a number of vulnerable population groups. A similar picture emerges for the share of recurrent property taxes in total household disposable income (gross of recurrent property taxes). Starting from close to $0 \%$ in 2006 , households had to pay a bit less than $4 \%$ of their disposable income a few years later, in 2014. 
Property taxes per capita by decile, in euro, 2007

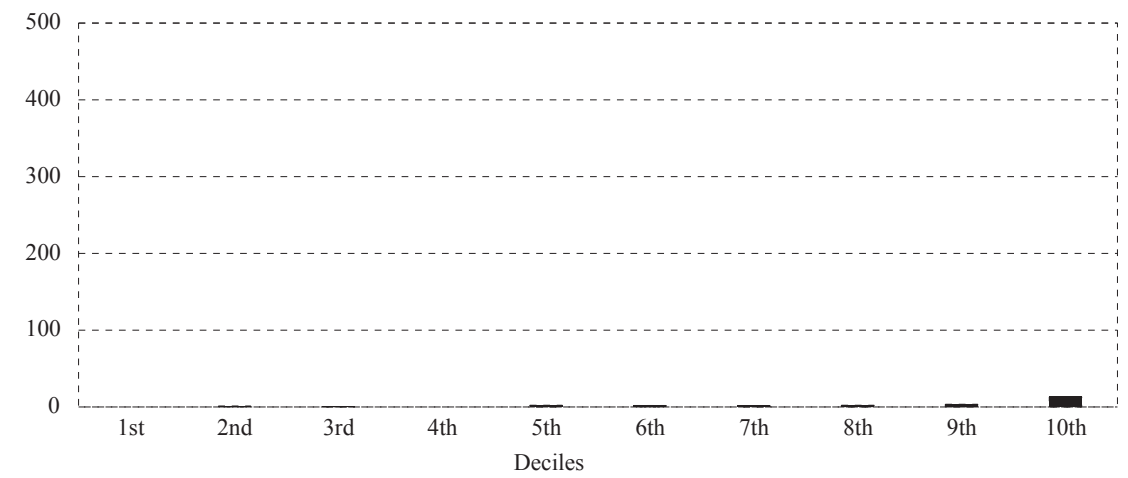

Source: ELSTAT, SILC (2008).

\section{GraPh 8ii}

Property taxes per capita by decile, in euro, 2012

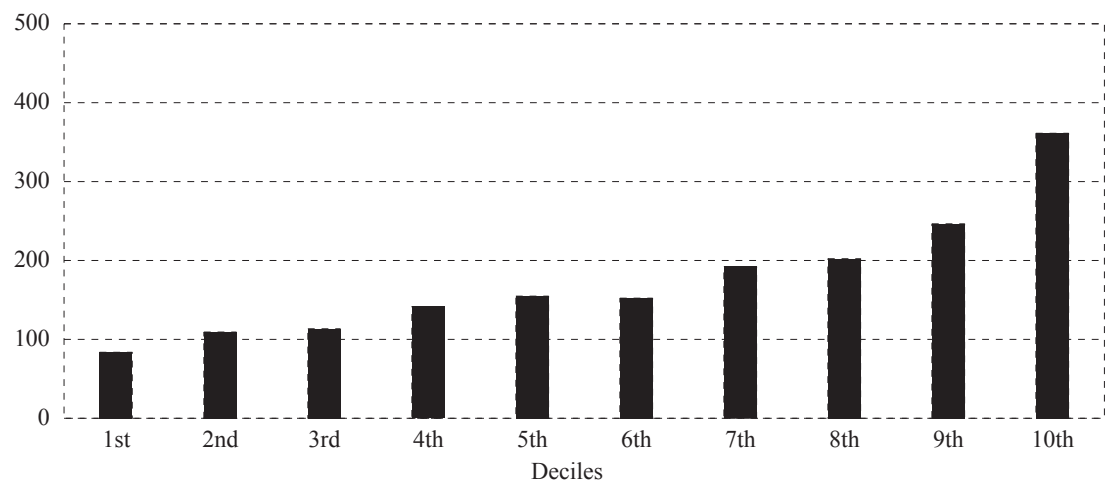

Source: ELSTAT, SILC (2013).

\section{Graph 8iii}

Property taxes per capita by decile, in euro, 2016

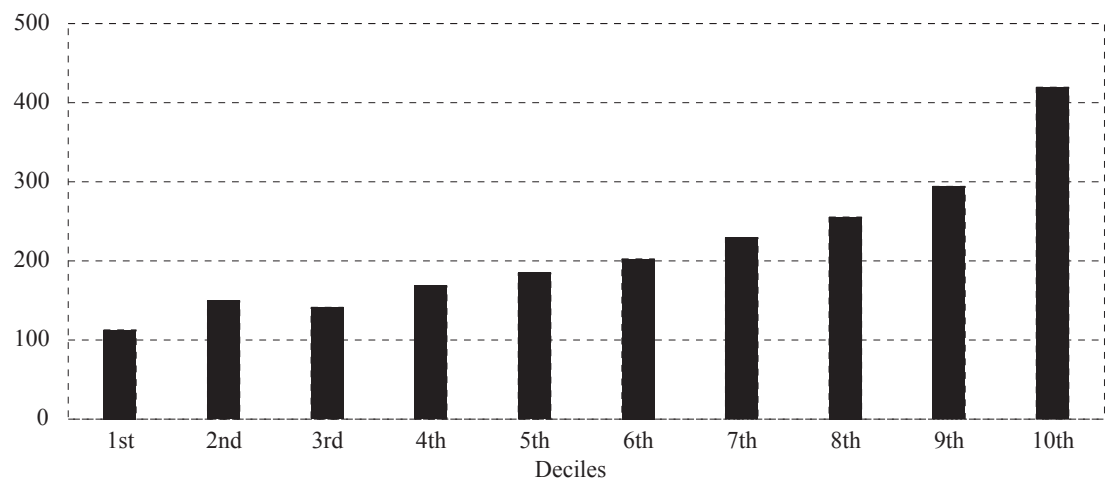

Source: ELSTAT, SILC (2017). 
Graphs 8i, 8ii and 8iii depict the level of recurrent property taxes per capita for each decile, when the population members are ranked from the poorest to the richest. For the sake of brevity, we present estimates for three years out of the whole period under examination. These years are 2007, 2012 and 2016 and are representative of the pre-crisis years and the years of the "maturity" of EETHDE and ENFIA, respectively.

For the majority of the population these taxes were zero in 2007. Even for the richest decile, the annual figure per capita was below 15 euro. On the contrary, in 2012 and 2016 all deciles paid substantial amounts and the mean payment per decile rose continuously when moving from the poorest to the richest decile (with minor exceptions between the fifth and the sixth decile in 2012 and second and the third decile in 2016). Mean per capita payments ranged between 84 (113) euro for the bottom decile to 361 (420) euro for the top decile in 2012 (2016).

Prima facie, the evidence of Graphs 8i, 8ii and 8iii could imply that the redistributive effect of the tax is progressive. However, to validate such a statement, we have to look at the tax as a share of distribution of disposable income per decile including the property tax (pre-tax distribution). The corresponding evidence is reported in Graphs 9i, 9ii and 9iii. The picture that emerges is anything but progressive, at least for 2012 and 2016. As expected, in 2007 the shares for all deciles are close to zero. In 2012, the share of the tax in the income of the bottom decile is $6.8 \%$, declining almost progressively up to the top decile where it is $2.3 \%$. The corresponding shares for 2016 are even higher; $8.5 \%$ and $2.9 \%$, respectively. To some extent, these results may be attributed to the fact that during the crisis a number of property-owning households became jobless, while long-term unemployment soared. Unemployment protection in Greece is quite inadequate, for the long-term unemployed it is almost non-existent, while in the years under consideration there was no benefit of last resort in the form a minimum income guarantee scheme. Hence, many households in the bottom decile had very limited monetary resources while the taxable value of their real estate assets was not so low and, as a result, the decile ratio of taxes to disposable income was high. All in all, the evidence of these graphs provides a very strong indication that the incidence of the recurrent property taxes introduced during the crisis was regressive. ${ }^{9}$

\footnotetext{
${ }^{9}$ This statement is in line with the vast majority of similar studies treating inequality and progressivity in relative terms. However, there is a strand of literature in which inequality and progressivity remain unchanged if the incomes of all population members change by the same amount (instead of the same proportion), (Blackorby and Donaldson, 1980; 1984). Using this approach, the evidence provided so far would point to the opposite direction, i.e. progressivity, since in absolute terms the property taxes paid by the rich are larger than those paid by the poor.
} 
Property taxes as share of disposable income by decile, in \%, 2007

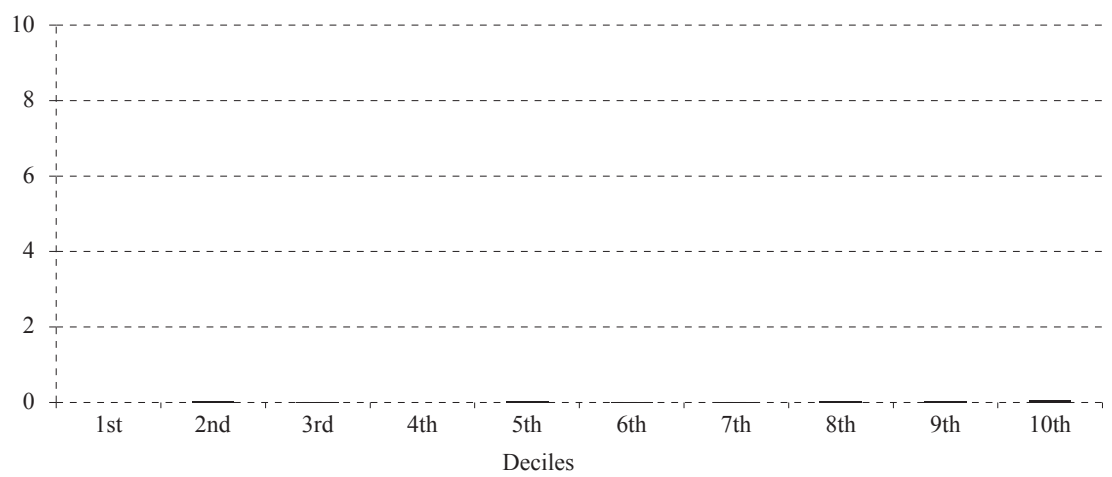

Source: ELSTAT, SILC (2008).

\section{GraPH 9ii}

Property taxes as share of disposable income by decile, in \%, 2012

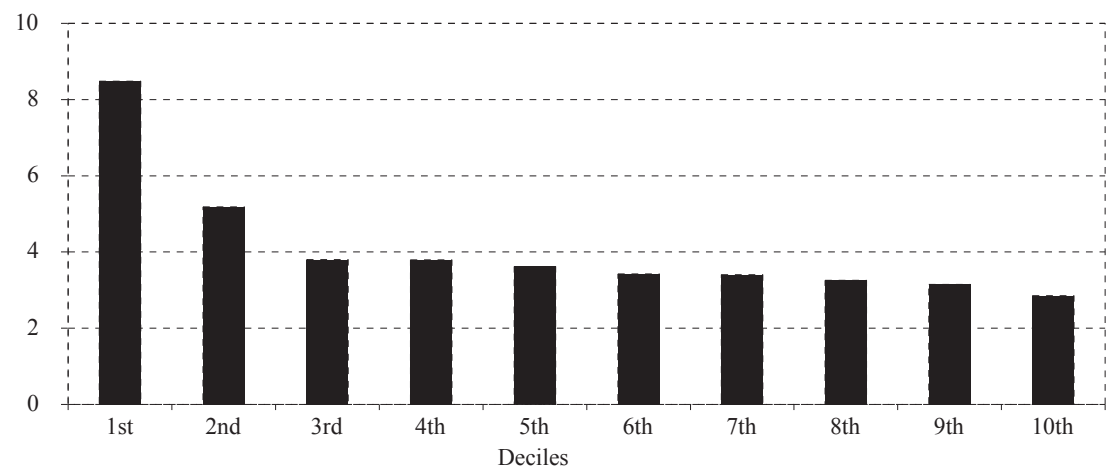

Source: ELSTAT, SILC (2013).

\section{Graph 9iii}

Property taxes as share of disposable income by decile, in \%, 2016

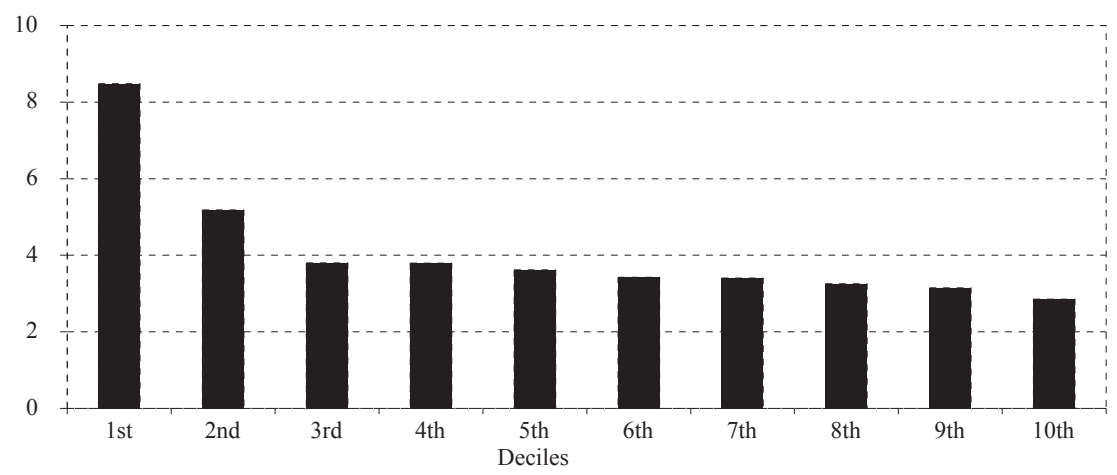

Source: ELSTAT, SILC (2017). 
GraPh 10i

Lorenz and concentration curve, 2007

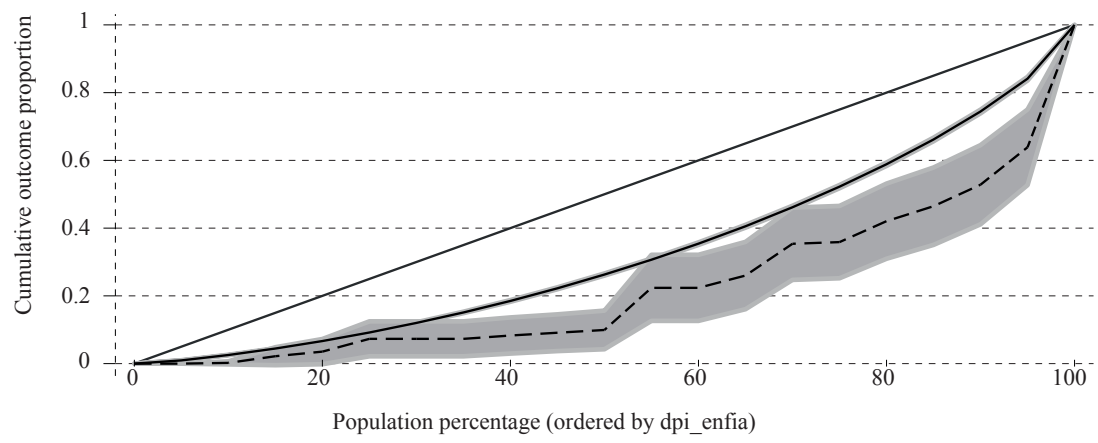

Lorenz_Disp. income

- - - - Concentration_Property taxes

Source: ELSTAT, SILC (2008).

\section{GraPh 10ii}

Lorenz and concentration curve, 2012

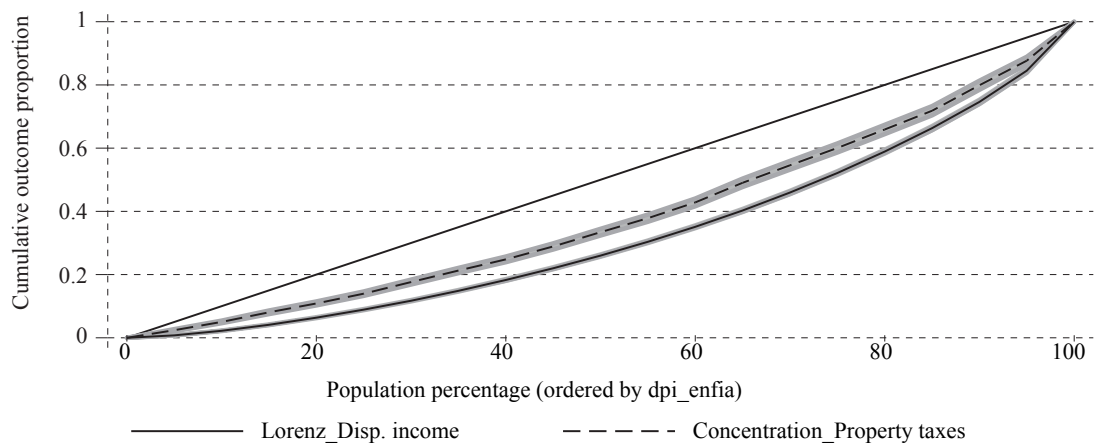

Source: ELSTAT, SILC (2013).

\section{GraPh 10iii}

Lorenz and concentration curve, 2016

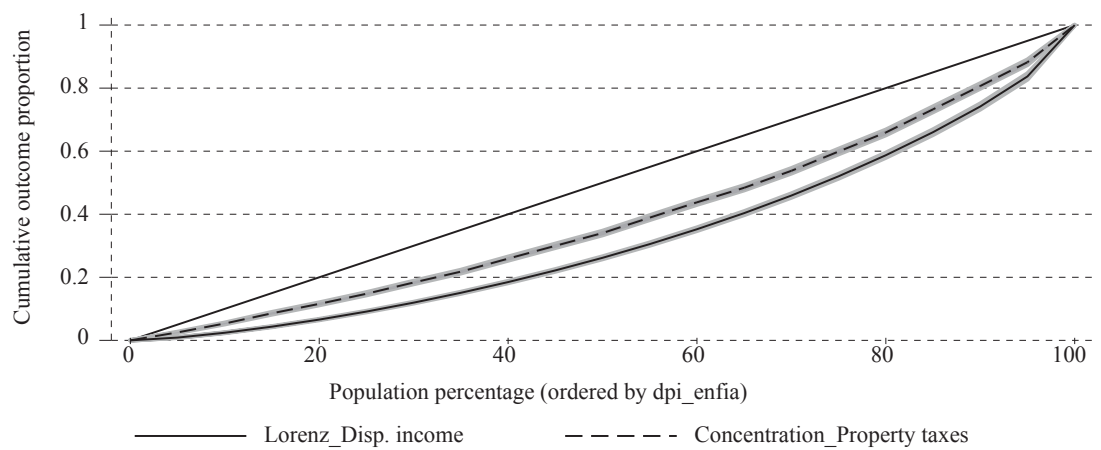

Source: ELSTAT, SILC (2017). 
Graphs 10i, 10ii and 10iii go a step further and show the Lorenz curves of the distribution of pre-tax equivalized income and the concentration curves of recurrent property taxes for the three years under consideration. The grey area around the concentration curves is the 5\% confidence interval for the corresponding points of the curves. In general, since tax is a negative income component, if the tax concentration curve lies above (below) the Lorenz curve of the pre-tax income distribution, the Lorenz curve of the post-tax income distribution is likely to lie below (above) the pre-tax Lorenz curve. Some interesting observations can be made. In 2007 the concentration curve lies below the Lorenz curve, implying that the property taxes of that year were progressive (the top 5\% of the distribution paid almost $40 \%$ of the, admittedly very low, total amount of the tax). However, the wide band of the confidence interval implies that safe conclusions are hard to draw. On the contrary, in both 2012 and 2016 the concentration curves lie above the Lorenz curve and the confidence intervals are pretty narrow. This is another indication that the post-tax distribution of income is likely to be more unequal than the pre-tax distribution.

\section{GraPh 11}

Reynolds-Smolenski (lhs) and Kakwani (rhs) progressivity indices, 2006-2019

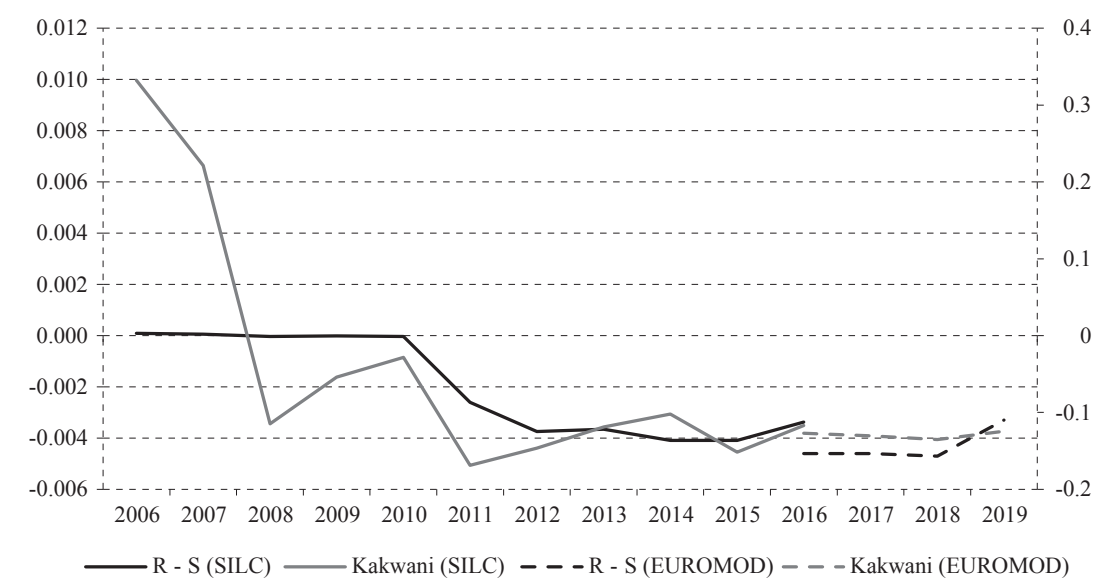

Source: ELSTAT, SILC (2007-2017) and EUROMOD.

Graph 11 depicts progressivity indices for all the years under examination. Estimates for the 2006-2016 period are derived directly from SILC data, while EUROMOD-based estimates are provided for the years 2016-2019. Naturally, the simulated estimates of EUROMOD do not coincide with those observed in the sample in 2016, but the differences are pretty low. Estimates of two indices of progressivity (and redistribution) are shown in the graph. The first is the index of Kakwani (1977), which essentially measures departures from proportionality and takes values between -1 and 1 ; the larger the value of the index is, the more progressive is the social intervention. However, this index is not affected by the size of the corresponding transfer (Enami, Lustig and Aranda, 2017). Estimates of the index are reported on the right vertical axis of the graph. The second index is that 
of Reynolds and Smolensky (1977) which, essentially, measures the difference between the Gini coefficient of the pre-tax income distribution and the Gini coefficient of the post-tax income distribution. It also takes values between -1 and 1 and the larger its value, the higher the progressivity of the social intervention. Unlike the former index, this one is sensitive to the size of the transfer. The index of Kakwani has a rather erratic pattern until 2010 but, in general, classifies the redistributive effects of the property taxes in the early years as progressive. On the contrary, the Reynolds-Smolensky index for the same period is always very close to zero, implying that the impact of the tax on measured inequality was negligible. For the period after the introduction of EETHDE and ENFIA, both indices move to negative territory, implying that the property tax reforms of that period were regressive. It is interesting to note that in the final year under consideration, when proportional cuts to ENFIA were introduced, the Kakwani index hardly moves while the Reynolds-Smolensky index records a decline in regressivity (the estimated value of the index increases from -0.047 to -0.033 ).

\section{GraPh 12}

Changes in inequality due to property taxation, in \%, 2006-2019

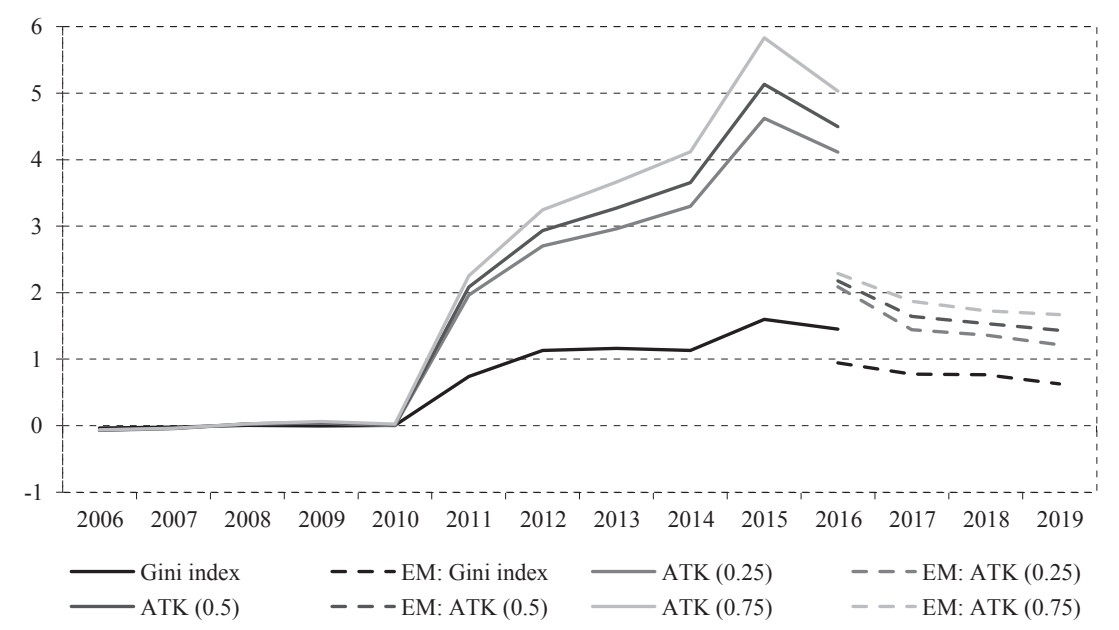

Source: ELSTAT, SILC (2007-2017) and EUROMOD.

Inequality indices were calculated both for the distribution of disposable income including property taxes (pre-tax distribution) and for the distribution of disposable income net of property taxes (post-tax distribution). The corresponding proportional changes in the estimates of the inequality indices due to recurrent immovable property taxes for each year are depicted in Graph 12. For the purposes of the graph, we use the Gini index and three members of the parametric family of Atkinson (1970) indices. In comparison to other indices of inequality, the Gini index is relatively more sensitive to changes close to the middle of the income distribution (Cowell, 2000). In the case of the Atkinson index, the inequality-aversion parameter is, successively, set at $0.25,0.5$ and 0.75 . Ceteris paribus, 
the higher the value of the inequality-aversion parameter, the more sensitive the index is to changes close to the bottom of the distribution. The evidence of Graph 12 shows that the effect of property taxation on the distribution of disposable income for the period 2006-2010 was very close to zero. In the following years the effect is negative and, in fact, the changes in inequality indices become increasingly larger between 2010 and 2015. In 2016 the impact is again inequalityincreasing, but the effect is smaller than that of 2015. The change in the value of the Gini index as a result of the immovable property tax reforms $(1.6 \%$ at the maximum) is smaller than the increase recorded in the Atkinson indices (between $4.6 \%$ and $5.8 \%$ at the peak). It is worth noting that the higher the inequalityaversion parameter of the Atkinson index the larger the proportional change in the value of the index. The changes in the estimates of inequality indices recorded using EUROMOD for 2016 are smaller than those recorded in the original SILC data, but the relative ranking of the indices remains the same. According to the evidence of Graph 12, for the period 2016-2019, the impact of recurrent property taxation remained regressive, but the changes introduced is these years moderated its inequality-increasing impact.

\section{GraPH 13}

Changes in relative poverty due to property taxation, in \%, 2006-2019

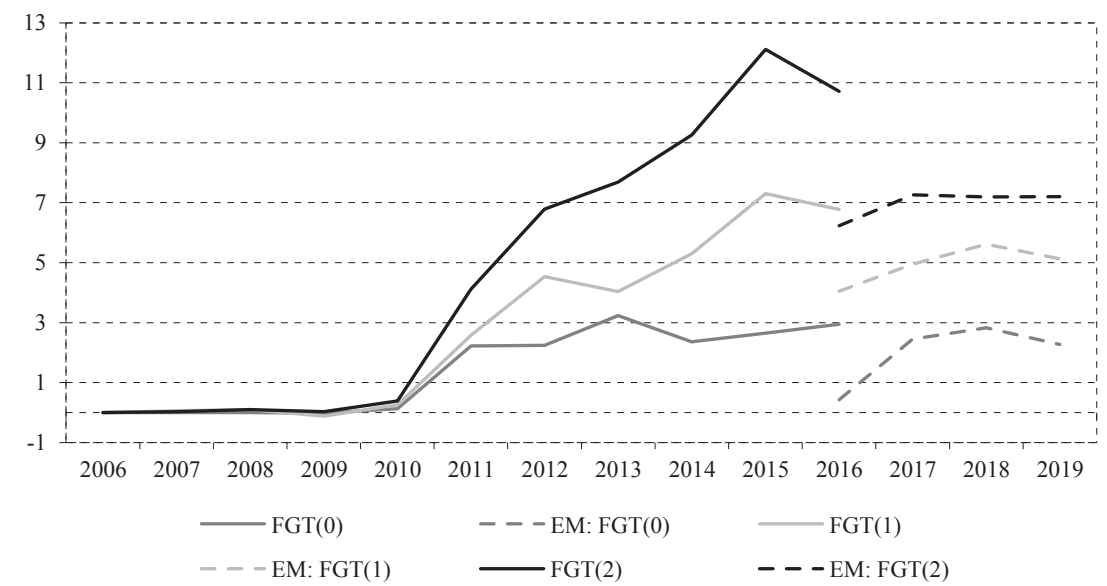

Source: ELSTAT, SILC (2007-2017) and EUROMOD.

Finally, the effects of these taxes on relative poverty are assessed in Graph 13. For the purposes of this graph, the poverty line is not held constant but is always set at $60 \%$ of the median income of the corresponding income distribution. Three members of the parametric Foster-Greer-Thorbecke (1984) (FGT) family of poverty indices are exploited for the purposes of this graph: the headcount ratio, $\operatorname{FGT}(0)$, which measures the proportion of the population falling below the poverty line, but is not sensitive to the severity of their poverty; FGT(1), which is the product of the headcount ratio and the average poverty gap (distance between the poverty line and the mean income of the poor divided by the poverty line); and FGT(2), which 
measures the product of the head count ratio by the squared poverty gap and, thus, unlike FGT(0) and FGT(1) is sensitive to the distribution of income among the poor. The results reported in Graph 13 are largely similar to those of Graph 12. There are minimal changes in the indices until 2010. In most cases we see increasingly larger rises in relative poverty between 2011 and 2015 and a smaller increase between 2015 and 2016 (at least for FGT(2) whose value in 2015 increases by more than $12 \%$ as a result of recurrent property taxes - the pattern of the other two is not entirely clear). The higher the poverty-aversion parameter of the index, the larger the recorded proportional change in relative poverty. Changes in the estimates of the poverty indices in 2016 are lower when simulated data are used instead of the original SILC data. However, the simulations of EUROMOD suggest that unlike the changes recorded in inequality indices for the period 2016-2018, the povertyincreasing impact of recurrent property taxes rose during this period. For the last year under examination the poverty-increasing effect of property taxes declines according to FGT(0) and FGT(1) but remains stable according to FGT(2). Nevertheless, it is clear that the reforms in the field of recurrent property taxation in the years of the Economic Adjustment Programs increased relative poverty.

\section{CONCLUSIONS}

The paper aimed to examine the distributional impact of recurrent property taxation in Greece. Until a few years ago recurrent property taxation played a minimal role in the Greek tax system. In the middle of the recent severe crisis, a new scheme of recurrent property taxation was introduced, initially covering only buildings connected to the electricity grid, but later extended to all types of real estate. The new tax had high collectability, boosted public revenues and substantially helped the fiscal stabilization effort of the country. In line with the experience of several other countries, this tax was also hugely unpopular.

Our results show that the distributional effect of the tax was clearly regressive. Although, on average, in absolute terms richer households paid higher recurrent property taxes than poorer households, the ratio of the tax to the pre-tax disposable income was substantially higher in the case of poorer households. As a consequence, ceteris paribus, inequality and (relative) poverty indices rose after the imposition of the tax. The result was stronger in the case of inequality indices that are relatively more sensitive to changes close to the bottom of the distribution and poverty indices that are sensitive to the distribution of income among the poor. Recent policy changes proportionately reducing the tax mitigated these effects. However, carefully designed tax relief may be needed if the aim is to keep the amount of tax revenues collected constant and at the same time neutralize its adverse distributional effects. Yet, taking it into account that the "grey economy" is extensive in Greece (Kelmanson et al., 2019), the link between property taxation and income criteria should be tackled with care in order to avoid increasing incentives for tax evasion.

\section{Disclosure statement}

No potential conflict of interest was reported by the authors. 


\section{REFERENCES}

1. Aaron, H. J., 1974. A New View of Property Tax Incidence. American Economic Review (64), pp. 212-221.

2. Almy, R., 2014. Valuation and Assessment of Immovable Property. OECD Working Papers on Fiscal Federalism, No. 19. https://doi. org/10.1787/5jz5pzvr28hk-en

3. Andriopoulou, E., Kanavitsa, E. and Tsakloglou, P., 2020. Decomposing poverty in hard times: Greece 2007-2016. Revue d'économie du développement, 27(2), pp. 125-168. https://doi.org/10.3917/edd.332.0125

4. Andriopoulou, E., Karakitsios, A. and Tsakloglou, P., 2018. Inequality and poverty in Greece: Changes in times of crisis. In: D., Katsikas, D. A. Sotiropoulos and M. Zafiropoulou, eds. Socioeconomic fragmentation and exclusion in Greece under the crisis Taxation Trends in the European Union, Publications Office of the European Union. London: Palgrave Macmillan, pp. 23-54. https://doi.org/10.1007/978-3-319-68798-8_2

5. Atkinson, A. B., 1970. On the measurement of inequality. Journal of Economic Theory 2(3), pp. 244-263.

6. Bank of Greece, 2019. Bulletin of Conjunctural Indicators, No. 189. Athens: Bank of Greece.

7. Blackorby, C. and Donaldson, D., 1980. A Theoretical Treatment of Indices of Absolute Inequality. International Economic Review, 21(1), pp. 107-136. https://doi.org/10.2307/2526243

8. Blackorby, C. and Donaldson, D., 1984. Ethical social index numbers and the measurement of effective tax/benefit progressivity. Canadian Journal of Economics, 17(4), pp. 683-694. https://doi.org/10.2307/135065

9. Cabral, M. and Hoxby, C., 2012. The Hated Property Tax: Salience, Tax Rates, and Tax Revolts. NBER Working Paper, No. 18514. https://doi.org/10.3386/ w18514

10. Chawla, R. K. and Wannell, T., 2003. Property taxes. Perspectives, Statistics Canada, 4(7), pp. 7-14.

11. Cowell, F. A., 2000. Measurement of inequality. In: Atkinson, A.B. and Bourguignon, F., eds. Handbook of Income Inequality I. Amsterdam: North Holland, pp. 87-166.

12. Davis, C. [et al.], 2009. Who Pays? A Distributional Analysis of the Tax Systems in all 50 States. Institute on Taxation and Economic Policy.

13. Diamond, P. A. and Mirrlees, J. A., 1971. Optimal taxation and public production I: Production efficiency. The American Economic Review, 61(1), pp. $8-27$.

14. Enami, A., Lustig, N. and Aranda, R., 2017. Analytic foundations: Measuring the redistributive impact of taxes and transfers. Working Paper, No. 446. https://doi.org/10.1787/888932958524 
15. European Commission, 2019. Taxation Trends in the European Union: Data for the EU Member States, Iceland and Norway. Luxembourg: Publications Office of the European Union.

16. Figari, F., Paulus, A. and Sutherland, H., 2015. Microsimulation and policy analysis. In: Handbook of income distribution, Vo. 2. Amsterdam: Elsevier, pp. 2141-2221. https://doi.org/10.1016/b978-0-444-59429-7.00025-x

17. Foster J. E., Greer J. and Thorbecke, E., 1984. A class of decomposable poverty measures. Econometrica, 52(3), pp. 761-766. https://doi. org/10.2307/1913475

18. Ioannides, Y. M. and Pissarides, C. A., 2015. Is the Greek crisis one of supply or demand? Brookings Papers on Economic Activity, pp. 349-383. https://doi. org/10.1353/eca.2015.0004

19. Joumard, I., Pisu, M. and Bloch, D., 2012. Tackling income inequality. $O E C D$ Journal: Economic Studies, (1), pp. 37-70. https://doi.org/10.1787/eco_studies-2012-5k95xd6165lt

20. Kakwani, N. C., 1977. Measurement of tax progressivity: an international comparison. The Economic Journal, 87(345), pp. 71-80. https://doi. org/10.2307/2231833

21. Kelmanson, B. [et al.], 2019. Explaining the shadow economy in Europe: size, causes and policy options. IMF Working Paper, WP 19/278. https://doi. org/10.5089/9781513520698.001

22. Kim, K. and Lambert, P. J., 2009. Redistributive effect of US taxes and public transfers, 1994-2004. Public Finance Review, 37(1), pp. 3-26. https://doi. org/10.1177/1091142108324423

23. Lyons, M., 2007. Lyons Inquiry into Local Government-Place-Shaping: A Shared Ambition for the Future of Local Government. London: The Stationery Office.

24. Marical, F., 2009. Les mécanismes de réduction des inégalités de revenus en 2008, in France Portrait Social - Edition 2009. Paris: INSEE.

25. Meghir, C. [et al.,] 2017, Beyond Austerity: Reforming the Greek Economy. Boston: MIT Press. https://doi.org/10.7551/mitpress/10082.001.0001

26. Mirrlees, J. [et al.], 2011. Tax by design. Oxford: Oxford University Press. https://doi.org/10.1111/j.1475-5890.2011.00140.x

27. Musgrave, R. A. and Musgrave, P. B., 1989. Public finance in theory and practice. New York: McGraw-Hill.

28. Norregaard, J., 2013. Taxing Immovable Property Revenue Potential and Implementation Challenges. IMF Working Paper, WP/13/129. https://doi. org/10.5089/9781484369050.001

29. Palameta, B. and Macredie, I., 2005. Property taxes relative to income. Perspectives, Statistics Canada, March, 6(3), pp. 14-24.

30. Ramsey, F. P., 1927. A contribution to the theory of taxation. The Economic Journal 37(145), pp. 47-61. 
31. Reynolds, M. and Smolensky, E., 1977. Public expenditures, taxes, and the distribution of Income: The United States, 1950, 1961, 1970. New York: Academic Press. https://doi.org/10.2307/2064531

32. Slack, E. and Bird, R., 2014. The political economy of property tax reform. OECD Working Papers on Fiscal Federalism, No. 18. https://doi. org/10.1787/5jz5pzvzv6r7-en

33. Sutherland, H. and Figari, F., 2013. EUROMOD: the European Union taxbenefit microsimulation model. International Journal of Microsimulation, 6(1), pp. 4-26. https://doi.org/10.34196/ijm.00075

34. Tammik, M., 2019. Baseline results from the EU28 EUROMOD: 2015-2018. EUROMOD Working Paper, EM6/19. https://doi.org/10.2139/ssrn.3302025

35. Tsakloglou, P. [et al.], 2016. A roadmap to exit the crisis: A new productive model for Greece. Athens: diaNEOsis (in Greek). 